\title{
THE EXPERIENCE OF THE PEOPLE'S REPUBLIC OF CHINA IN THE DETERMINATION OF THE RESULTS OF PROFESSIONAL TRAINING OF BACHELORS OF BUSINESS ECONOMICS
}

\author{
Gao Wanquan ${ }^{1}$, Kseniia Tsytsiura ${ }^{2}$, \\ 1 Director of the College English Department, English lecturer of Jiaxing University, Jiaxing, China \\ http://orcid.org/0000-0001-8114-5129, e-mail: billgwq@gmail.com \\ 2 post-graduate student of the Institute of Vocational Education and Training of the National Academy of Educational Sciences of \\ Ukraine, foreign expert of Jiaxing University, Jiaxing, China \\ http://orcid.org/0000-0002-4606-9287, e-mail: ksenija.tsytsiura@gmail.com
}

\begin{abstract}
.
Relevance. In the times of economic transformation on the way to the market relations, Ukraine needs highly qualified economists who have high qualification for working in both domestic and international economies. That is why currently one of the priorities of the vocational education system is to educate the competitive specialist who has a high level of professional competence. Analysis of literature suggests that the problem of the formation of professional competence of the future specialists has always interested the scientists, but because of the modernization of the educational system of our country it has acquired particular relevance.

The article aim is to identify and characterize the features of determining the results of training of the future economists on the example of the state university in China.

Methods: The research methods used during the study are:

- theoretical methods: analysis (to study the educational and professional program of the state Chinese University and determine the results of training of future Bachelors majoring in Business Economics in Chinese universities), comparison (to identify the positive features of the formation of the professional competence of future Bachelors in China's business economy), generalization (to formulate conclusions and recommendations for applying the results of training of Bachelors of Business Economics in Ukrainian education).

- empirical methods: observational (direct observation of the educational process at a state university in the People's Republic of China) - to determine the specific features of determining and studying the results of a professional training of Bachelors of Business Economics at a Chinese university.

Results. The article outlines and describes the specific features of determination of the results of the training of future Bachelors majoring in Business Economics which have been given and analyzed on the example of the university in China. The structure of the professional competence of future Bachelors of Business Economics is considered in accordance with the educational and professional program of Chinese University. Positive characteristics of the formation of the professional competence of future Bachelors in China's business economy are identified and the possibility of their application in higher economic education in Ukraine is considered.

Conclusions. The conclusion is justified that the results of professional training of future Bachelors of Business Economics in Ukraine and Europe, as well as in China, are determined on the basis of the competence approach. The analysis of the educational and professional programs of universities in China allowed us to determine such competence groups in the professional competence as follows: general (integral) competencies, which mean possession of flexible («soft») skills; personal (subject) competencies, which include values, motivations and characteristics of graduates; professional (subject-specific) competencies which include «solid» skills. Using the positive experience of professional training of future Bachelors of Business Economics in China can significantly improve current economic education in Ukraine.
\end{abstract}

Keywords: economic education; educational and professional program; professional competence; structure of professional competence of an economist; formation of professional competence of an economist. 
Introduction. Market relations, the integration of our country into the international community, comprehensive informatization of society need to improve the quality and level of economic activity of enterprises and organizations. It leads to the new, more stringent requirements for Bachelors of Business Economics. That is why today the training of a competitive economist who has a high level of professional competence is one of the priority tasks of the higher education system in the field of Business Economics. It is necessary to study the experience of those countries in which the training of Bachelors of Business Economics is carried out at a high level. As a rule, the basis of this training is the application of a competency-based approach; it is efficient in the countries of the European Union and in China.

Materials. Analysis of the sociological, educational, cultural and economic literature suggests that the problem of the formation of professional competence of various scientific positions has always interested scientists, but in the transformational period of our country it has acquired particular relevance. The Chinese professional education experience was studied by N. Borevska, S. Gala, I.Serhiichuk.

The issues of formation of professional competence of a specialist of Economics are considered in the research of numerous scientists, namely: the philosophical and methodological approach (V. Andrushchenko, Yu. Afanasiev, V. Bondarenko, H. Vasianovych, D. Dzhola, O. Dubaseniuk, I. Ziaziun, V. Kremen, M. Mykhalchenko, P. Saukh); study of particular types of professional competence (M. Bohatyrova, I. Vorobiova, V. Safonova, V. Topalova - sociocultural competence; R. Hryshkova, N. Ihnatenko, V. Kalinin - development of the foreign language sociocultural competence; $\mathrm{V}$. Liventsova - the culture of professional communication of future managers; L. Savenkova - communicative competence, V. Cherevko - communicative competence of the future managers in the course of training); training of specialists at the economic university (M. Artiushyna, L. Volkova - foreign language communicative competence of future specialists of financial and economic major; N. Zamkova - development of professional qualities of the future managers of external economic activity in the process of learning foreign languages; H. Romanov, O. Yatsyshyn - development of motivation for studying a foreign language by students of economic major). However, the results of the analysis of scientific literature convince us that the problem of the formation of professional competence in future Bachelors of Business Economics is inadequately treated and needs development from the viewpoint of foreign experience.

The article aim is to identify and characterize the features of determining the results of training of the future economists on the example of the state university in the People's Republic of China.

The research methods which were used during the study are as follows:

- theoretical methods: analysis (to study the educational and professional program of the Chinese University and determine the results of future Bachelors training in the Business Economics major in Chinese universities), observation (to determine the specific features of formation of results of Bachelors' training), the comparison (to identify the positive features of the formation of professional competence of future Bachelors in China business economy), generalization (to formulate conclusions and recommendations on the use of professional results of the Bachelors of Business Economics for application in the domestic education).

- empirical methods: observational (direct observation of the educational process at a university in the People's Republic of China) - to determine the specific features of identifying and researching the results of professional training of Bachelors of the Business Economics major at a Chinese university.

Results and discussions. The determination of the results of professional training of specialists in general and economists in particular is carried out on the basis of the competence approach in different countries of the world, therefore, the analysis of the specific features of the process of the formation of professional competence of the future Bachelors of Business Economics and its component structure abroad is very relevant.

Within the framework of the Business Economics major in China, individual competencies also significantly influence the level of professional competence, the possession of which can determine the competitiveness of a modern specialist. Let us analyze them on the example of Jiaxing University in China.

Requirements for the professional competence of the Bachelor of the Business Economics major are defined in the educational and professional program, which is the standard of higher education in China (Educational and professional program for Bachelor's Degree, 2018). This program is the basis for the development of the curricula for all academic disciplines in higher education institutions of China. They include the structure of the content of disciplines in higher education institutions, they set the scope of educational material for students to master, the means of determination of the quality level of an educational and professional training of the specialist.

The educational qualification program of Chinese universities is aimed at meeting the high level of students' requirements for language training (English), professional knowledge and specialized skills that are necessary for the general development of the international business economy. In addition, the Business 
Economics training program aims at providing students with an understanding of the English language and culture, financial and legal operations abroad, opportunities for learning, communication practice in a business environment in global view, including English, management, a specific spirit of innovation and entrepreneurship (Educational and professional program for Bachelor's Degree, 2018).

The structure of professional competence of the future Bachelor in Business Economics in Chinese universities has the following components: general (integral) competencies, personal (subject) competencies and professional (subject-specific) competencies.

General (integral) competencies embody the complex requirements for the quality of education imposed on the future Bachelor in Business Economics at the Chinese University (Educational and professional program for Bachelor's Degree, 2018) and include many flexible, or "soft", skills that are responsible for successful participation in the workflow, high productivity and as opposed to specialized skills are not related to a specific field. The program indicates the following:

- a positive outlook on life and entrepreneurship;

- a profound connection to national traditions and cultures;

- a high cross-cultural humanistic literacy and knowledge horizon;

- a spirit of contribution to the nation and service to the society;

- a mastery of professional theoretical knowledge and practical skills, with the foundational quality to transform professional knowledge into international application;

- a fine spirit for cross-cultural teamwork and an open global vision;

- a professional ethics with adherence to patriotism, honesty and trustworthiness.

The requirements for personal, or subject, competencies of a graduate of the Chinese University (Educational and professional program for Bachelor's Degree, 2018) majoring in Business Economics are:

- understanding the operational rules of cross-border e-commerce and international business management, as well as the basic rules and procedures of the World Trade Organization,

- being familiar with the cultures, policies, regulations and international practices in international businesses, economics and trade work in the context of the One Belt One Road initiative;

- recognizing future trends and knowledge requirements for the managerial development in cross-border e-commerce and international business;

- possessing a high level of professional responsibility and national responsibility;
- maintaining a rigorous cross-cultural management style and healthy psychological quality;

- having a fine professional spirit for cooperation within cross-cultural teams;

- preliminary formation of scientific thinking method that meets international standards, and possession of an open sense of innovation, spirit of innovation and practical innovative skills in cross-cultural settings.

According to the educational and professional program (Educational and professional program for Bachelor's Degree, 2018), the basic professional or subject-specific competencies that the future Bachelor in Business Economics should master are as follows:

- solid theoretical foundation in international business economics and trade and self-sustainble skills in both offline / online practices, international business management skills;

- ability to use modern information technologies of the Internet to handle international trade businesses, to understand the modes of operations and transactions procedures in international e-commerce;

- basic technologies and skills for cross-border e-commerce applications and their management;

- ability to process, analyze, judge and make decisions based on big data in global trade and international business management issues;

- ability to conduct cross-cultural exchanges and communication around business management, organize and coordinate international business activities, and form self-developing capabilities for strategic planning and global leadership;

- proficiency and specialization in at least one foreign language (especially English), and its corresponding international business etiquette and negotiation skills, with the ability for coordination, communication, and expression in spoken and text forms;

- skills for modern information search and data retrieval within specialist fields, and sustainable ability for continued self-learning.

We may notice that many of these skills are "solid," that is, the ability to perform specific functional tasks. Such skills are stable, clearly visible, measurable, and refined with specific designs; they are included in the list of requirements set out in job descriptions; they are easily disunited into some simple final operations.

The results of training under the educational programs in Ukraine are also determined on the basis of the competency-based approach. Within a particular profession, the level of professional competence is significantly affected by individual competencies that may enhance the competitiveness of a specialist in the modern world.

In Ukraine, the demands for the professional competence of a specialist in economics are established in the educational and professional program (EPP) which 
must satisfy the standards of higher education. EPP is the basis for the development of programs of all academic disciplines in the higher educational institutions. They describe the structure of the content of disciplines in the the higher educational institutions, set the amount of educational material for students to master, identify the tools to determine the quality level of educational and professional training of a specialist.

For the study of professional competence of future economists, it is relevant to take into account the results of the scientists' research about the essential competencies included in their composition. The process of developing these competencies has caused the occurrence of different classifications. Now let us consider them in detail.

S. Molchanov (2008) defines professional competence as the scope of abilities, terms of reference in the field of professional and educational activity. In the narrower sense, professional competence is interpreted by him as a circle of issues in which the subject has knowledge, experience, the totality of which represents the socio-professional status and professional qualifications as well as some personal, individual characteristics that enable the implementation of the special professional activity.

A. Busyhina (2003) considers professional competence as an integral systemic feature of an individual, the structural elements of which are professionally meaningful (the fundamental part assuming the presence of theoretical knowledge within the profession, that ensures awareness of the content of the professional activity); the professional activity (practical element, including professional knowledge and skills), tested in action, learned by the person as the valid one) and professional-personal ingredient, including professional and personal traits of a specialist as a person, an individual, and a coordinator of the activity.

O. Bondareva (2003) identifies the following components of professional competence of a specialist: motivational-volitional, functional, communicative and reflective one. All of these components are integrated into the researcher's work into one of the most synthesized formations - communicative and functional competence, which is an integrative quality of the personality of a specialist in Economics.

V. Vvedenskyi (2003) suggests five components of the structure of the professional competence. They include the communicative ability, the main elements of which are: emotional stability (connected with adaptability), extroversion (associated with status and experienced leadership), the ability to design-forward and feedback; speech skills; listening skills; the ability to reward; delicacy, ability to freely communicate; regulatory competence implies the ability to manage the behaviour; information competence includes the volume of information about oneself, about the work experience of other colleagues.

Recently, there have been substantial changes in the organization of labour in industries. Professional activity of an economist is based on interactions with colleagues, organization of joint activities, which allows us to talk about the necessity to develop skills of the future economists in accordance with the classification of psychological requirements of professions such as "Person to Person", including the desire for communication; the ability to communicate with strangers easily; goodwill, responsiveness, endurance, the capability to regulate emotions; the ability to analyze the behaviour, to understand the intentions and moods of other people; the ability to understand the relationships among people; knowledge of the human psychology.

It is important to note that the reform of the higher school of Ukraine in the context of the Bologna process predetermines the need to improve and enhance the quality of language education in Ukraine. Without students' knowledge of at least one foreign language, it is impossible to fulfil the main provisions of the Bologna Declaration: adaptation to the norms and standards of the European educational space, mobility, and professional competition can only take place if university graduates have a knowledge of the foreign language and the developed communication skills in relevant academic and professional situations and everyday communication. "In the context of increasing speed, quantity, multidirectionality and multilingualism of information flows as well as an increase in the diversity and degree of penetration of electronic media into the life, the ability to quickly and correctly perceive and interpret the content in foreign language is a fundamental factor in making the right management decisions," R. Gottlieb believes (2009).

Since language and culture act as the principal personal vocational-forming factors in the learning process, there is the reason to talk about the cultural and language training of a specialist, which is offered by the educational and professional program of universities in China.

Knowledge of a foreign language and foreign culture for the Bachelor of Business Economics is an integral component of professional competence in both China and Ukraine. The introduction of the term "intercultural competence" for the field of economics is explained by the fact that a specialist in this field should use a foreign language as a means of communication, taking into account the specificity of the linguacultural community, the specifics of particular concepts in their own and other professional cultures, having the ability to distinguish and differentiate between the general and the specific (Artemova, 2008). 
Professional intercultural communication takes place in business contacts. In the process of intercultural professional communication, information is exchanged, contacts are established. Modern pedagogy has dealt with the task of teaching the basics of the intercultural competence of Economics specialists. Moreover, this approach to teaching a foreign language, in particular, is noted as necessary one by both economists and educators as well as foreign language teachers. It is due both to the needs of the modern market for economists and contemporary requirements for a qualified pedagogical process (Educational and professional program for Bachelor's Degree, 2018).

Conclusions. The results of professional training of future Bachelors of Business Economics both in Ukraine and Europe and in China are determined on the basis of the competency approach. The analysis of the educational and professional programs of universities in China allowed us to determine such competence groups in the professional competence as follows: general (integral) competencies, which mean possession of flexible ("soft") skills; personal (subject) competencies, which include values, motivations and characteristics of graduates; professional (subject-specific) competencies which include "solid" skills.

As we can see, the educational and professional program of Jiaxing University in China (Educational and professional program for Bachelor's Degree, 2018) especially emphasizes the need for knowledge of a foreign language and Internet technologies, together with the specific features of business etiquette and culture of foreign countries for the implementation of successful economic activities. Using the positive experience of professional training of Chinese future Bachelors of Business Economics we can significantly improve modern economic education in Ukraine.

\section{List of referenñås}

Артемова, Л.В., 2008. Педагогіка і методика вищзої школи: Навчально-методичний посібник. Київ: Кондор.

Артюшина, М. В., 2009. Психологічні та педагогічні основи підготовки студентів економічних спеціальностей до інновачійної діяльності: монографія. Київ: КНЕУ.

Бондарева, Е.В., 2003. Профессиональная компетентность специалиста в условиях становления информационного общества. Вестник Волгоградского гос. ун-та. Сер. 6. Университетское образование, 6, с. 44-48.

Боревская, Н.Е., 2012. Обеспечение доступности и привлекательности среднего профессионального образования в КНР. Педагогика, 7, с. 109-119.

Бусыгина, А.Л., 2003. Профессор-профессия: теория проектирования содержания образования преподавателя вуза. Изд. 2-е, испр. и доп. Самара: Изд. СамСПУ.

Введенский, В.Н., 2003. Моделирование профессиональной компетентности педагога. Педагогика, 10, с. 51-55.

Волкова, Н.П., 2007. Сутність і компоненти компетентності майбутнього вчителя у здійсненні професійно - педагогічної комунікації. Педагогіка і психологія формування творчої особистості: проблеми і пошуки, 42, с. $103-111$.

Гала, С. В., 2011. Із досвіду реформування вищої освіти Китаю. Економіка і держава, 18, с. 52-55.

Головко, В.І., Мінченко, А.В. та Шаманська, В.М., 2006. Фінансово-економічна діяльність підприємства: контроль, аналіз та безпека: навч. посіб. Київ: Центр навчальної літератури.

Готлиб, Р.А., 2009. Социальная востребованность знания иностранного языка. Социологические исследования, 2, с. $122-127$.

Зимняя, И.А., 2004. Ключевые компетентности какрезультативно-иелевая основа компетентностного подхода в образовании. Авторская версия. Москва: Исследоват. центр проблем качества подгот. специалистов.

Молчанов, С.Г., 2008. Теория и практика аттестации педагогических и руководящих работников образовательных учреждений. Челябинск: Челябин. гос. у-т.

Освітньо-професійна програма для ступеня бакалавра, 2018. Цзясін: Видавництво академічного офісу Цзясінського університету, 2018.

Романова, Г. М., 2009. Психолого-педагогічна підготовка як чинник професійної самореалізації викладачів економічного університету. Вісник Львівського університету, 3(25), с. 167-175.

Сергійчук, І. М., 2006. Китай у нові та новітні часи: практикум: навч. посіб. Суми: ВТД «Університетська книга».

Melnyk O., 2017. Perspectives of usage of positive German experience in organization of bachelor program in economics and business education at Ukrainian universities. Науковий вісник Інституту професійно-технічної освіти НАПН Украӥни. Професійна педагогіка, 13, с. 139-144.

\section{Translated \& Transliterated}

Artemova, L.V., 2008. Pedahohika i metodyka vyshchoi shkoly [Pedagogy and methods of higher education]. Navchalnometodychnyi posibnyk [Education and methodical manual]. Kyiv, Kondor, [in Ukrainian].

Artiushyna, M.V., 2009. Psykholohichni ta pedahohichni osnovy pidhotovky studentiv ekonomichnykh spetsialnostei do innovatsiinoi diialnosti: monohrafia [Psychological and pedagogical bases of preparation of students of economic 
majors for innovative activities: monograph]. KNEU, [in Ukrainian].

Bondareva, E.V., 2003. Professyonalnaia kompetentnost spetsyalysta v uslovyiakh stanovlenyia ynformatsyonnoho obshchestva [Professional competence of the specialist in the conditions of formation of the information society]. Vestnik Volgogradskogo gos. un-ta. Ser. 6. Universitetskoe obrazovanie [Bulletin of Volgograd National University], 6, s. 44-48, [in Russian].

Borevskaya, N.E., 2012. Obespechenie dostupnosti i privlekatelnosti srednego professionalnogo obrazovaniya v KNR [Ensuring accessibility and attractiveness of secondary vocational education in China]. Pedagogika [Pedagogy], 7, s. 109-119, [in Russian].

Busyigina, A.L., 2003. Professor - professiya: teoriya proektirovaniya soderzhaniya obrazovaniya prepodavatelya vuza [Professor - profession: theory of designing the content of education of a university teacher]. Samara, Izd. SamSPU, [in Russian].

Vvedenskiy, V.N., 2003. Modelirovanie professionalnoy kompetentnosti pedagoga [Modeling the professional competence of a teacher]. Pedagogika [Pedagogy], 10, s. 51-55, [in Russian].

Volkova, N.P., 2007. Sutnist i komponenty kompetentnosti maibutnoho vchytelia u zdiisnenni profesiino - pedahohichnoi komunikatsii [The meaning and components of competence of the future teacher in implemetation of professional and pedagogical communication]. Pedahohika i psykholohiia formuvannia tvorchoi osobystosti: problemy i poshuky: Zb. nauk. prats. [Pedagogy and psychology of formation of creative personality: problems and solutions: Collection of scientific works], 42, s. 103-111, [in Ukrainian].

Hala, S. V., 2011. Iz dosvidu reformuvannia vyshchoi osvity Kytaiu [From the experience of reforming higher education in China]. Ekonomika i derzhava [Economy and state], 18, pp.52-55, [in Ukrainian].

Holovko, V.I., Minchenko A.V. ta Shamanska V.M., 2006. Finansovo-ekonomichna diialnist pidpryiemstva: kontrol, analiz ta bezpeka [Financial and economic activity of the enterprise: control, analysis and security]. K.: Tsentr navchalnoi literatury [Center for Educational Literature], [in Ukrainian].

Gotlib, R.A., 2009. Sotsialnaya vostrebovannost znaniya inostrannogo yazyika [Social demand for knowledge of a foreign language]. Sotsiologicheskie issledovaniya [Sociological research], 2, s. 122-127, [in Russian].

Zimnyaya, I.A., 2004. Klyuchevyie kompetentnosti kak rezultativno-tselevaya osnova kompetentnostnogo podhoda $v$ obrazovanii. Avtorskaya versiya. [Key competences as effectively-targeted basis of competence approach in education. Author's version]. Moskva: Issledovat. tsentr problem kachestva podgot. spetsialistov [Research Center for the Problems of Quality Training of Specialists], [in Russian].

Molchanov, S.G., 2008. Teoriya i praktika attestatsii pedagogicheskih i rukovodyaschih rabotnikov obrazovatelnyih uchrezhdeniy [Theory and practice of attestation of pedagogical and managerial employees of educational institutions]. Chelyabinsk: Chelyabin. gos. u-t [Chelyabinsk state university], [in Russian].

Osvitno-profesiina prohrama dlia stupenia bakalavra [Educational and professional program for Bachelor's Degree], 2018. Tsziasin [Jiaxing]: Vydavnytstvo akademichnoho ofisu Tsziasinskoho universytetu [Jiaxing University Academic Office Publishers], [in Ukrainian].

Romanova, H. M., 2009. Psykholoho-pedahohichna pidhotovka yak chynnyk profesiinoi samorealizatsii vykladachiv ekonomichnoho universytetu [Psychological and pedagogical training as a factor of professional self-realization of teachers of the economic university]. Visnyk Lvivskoho universytetu [Bulletin of Lviv University], 3(25), s. 167-175, [in Ukrainian].

Serhiichuk, I. M., 2006. Kytai u novi ta novitni chasy: praktykum: navchalno-metodychnyi posibnyk [China in new and modern times: practicum: education and methodical manual]. Sumy: VTD «Universytetska knyha», [in Ukrainian].

Melnyk O., 2017. Perspectives of usage of positive German experience in organization of bachelor program in economics and business education at Ukrainian universities. Naukovyi visnyk Instytutu profesiino-tekhnichnoi osvity NAPN Ukrainy. Profesiina pedahohika [Scientific Bulletin of the Institute of Vocational Education of the National Academy of Pedagogical Sciences of Ukraine. Professional Pedagogy], 13, s. 139-144, [in English].

\title{
Досвід Китайської Народної Республіки у визначенні результатів професійної підготовки бакалаврів $з$ бізнес-економіки
}

\author{
Гао Ванчуен ${ }^{1}$, Ксенія Цицюра ${ }^{2}$,
}

\author{
директор кафедри англійської мови, викладач англійської мови Цзясінського університету, м. Цзясін, КНР \\ 2 аспірант Інституту професійно-технічної освіти НАПН України, іноземний експерт Цзясінського університету, м. Цзясін, \\ KHP
}

\section{Реферат.}

Актуальність. Сьогодні на шляху до повноцінних ринкових відносин Україна переживає часи глобальних економічних перетворень. У зв’язку з цим, країні необхідні спеціалісти з економіки для висококваліфікованої роботи як у вітчизняній, так і в міжнародній економіці. Але успіх у професійній кар'єрі можливий тільки за умов конкурентоспроможності випускників на ринку праці. Саме тому наразі одним із першочергових завдань системи професійної освіти є підготовка конкурентоспроможних фахівців, які мають високий рівень професійної компетентності. Аналіз літератури з соціології, педагогіки, культурології та економіки свідчить про те, що науковців 
завжди цікавило питання формування професійної компетентності майбутніх спеціалістів з економіки, але останнім часом воно стало найбільш актуальним через те, що українська освіта знаходиться у стані модернізації.

Mета: виокремити та охарактеризувати особливості визначення результатів підготовки майбутніх економістів на прикладі державного університету в Китайській Народній Республіці.

Методи, що використовувалися нами під час дослідження:

- теоретичні: аналіз (для дослідження освітньо-професійної програми Китайського університету та визначення результатів з підготовки майбутніх бакалаврів зі спеціальності “Бізнес-економіка” у вищих навчальних закладах Китаю), порівняння (для виявлення позитивних рис формування професійної компетентності майбутніх бакалаврів 3 бізнес-економіки Китаю), узагальнення (для формулювання висновків і рекомендацій щодо використання результатів професійної підготовки бакалаврів з “Бізнес-економіки” для використання у вітчизняній освіті).

- емпіричні: обсерваційні (пряме спостереження навчального процесу в університеті в Китайській Народній Республіці) - для встановлення особливостей визначення та дослідження результатів професійної підготовки бакалаврів за спеціальністю "Бізнес-економіка" в китайському університеті.

Результати: виокремлено та охарактеризовано особливості визначення результатів підготовки майбутніх бакалаврів зі спеціальності “Бізнес-економіка” у вищих навчальних закладах на прикладі університету в Китайській Народній Республіці; розглянуто структуру професійної компетентності майбутніх бакалаврів з бізнес-економіки згідно з освітньо-професійною програмою китайського університету; визначено позитивні риси формування професійної компетентності майбутніх бакалаврів з бізнес-економіки Китаю та можливості їх використання у вищій економічній освіті в Україні.

Висновки: результати професійної підготовки майбутніх бакалаврів з бізнес-економіки як в Україні та Свропі, так і в Китаї, визначаються на основі компетентнісного підходу; аналіз освітньо-професійних програм університетів Китаю дав змогу виокремити у складі професійної компетентності загальні (інтегральні) компетентності, особистісні (суб'єктні) та фахові (предметно-спеціальні) компетентності; використання позитивного досвіду професійної підготовки майбутніх бакалаврів з бізнес-економіки Китаю може покращити сучасну економічну освіту в Україні.

Ключові слова: економічна освіта, освітньо-професійна програма, професійна компетентність, структура професійної компетентності економіста, формування професійної компетентності економіста.

Received: 14 August 2019

Accepted: 04 November 2019 